\title{
Analysis of the Language Delay Development in Early Children (Case Study in Bojongsoang Village, Bandung District)
}

\author{
$1^{\text {st }}$ Mulyanti \\ Aisyiyah Bandung School of Health Sciences \\ Bandung, Indonesia \\ yanti120511@gmail.com
}

\begin{abstract}
Language development is significant language and speech skills are indicators of all children's development. Speech delay (speech delay) in early childhood is when the level of speech development is below the level of quality of speech development of children of the same age that can knowing from the accuracy of the use of words. A child will not be able to talk without the support of his environment. The purpose of this study was to determine the factors that influence the occurrence of language development delays and the role of parents in early childhood. This research uses a qualitative method with a case study approach. The unit of analysis is language development delay. There were six speakers in this study consisting of four primary speakers. Data collection techniques in this study used interview techniques, observations. The data validity technique used in this study is the perseverance of field observations and triangulation techniques. The results of the study there are 13 factors that influence the delay in language development in early childhood: multilingualism, lack of knowledge about language development barriers, health, intelligence, physical readiness to speak, mental readiness to speak, good things to emulate, lack of motivation to speak, habits children when watching television, lack of knowledge of people around the child, gender, and relationships with peers.
\end{abstract}

Keywords-Early Children, Language Development, Speech Delay.

\section{INTRODUCTION}

Health development is part of efforts to develop a whole person, among others, organized through the health efforts of children or toddlers, which are carried out as early as possible since the child or baby is still in the womb. Considering that the number of children under five in Indonesia is very large, which is around $12 \%$ of the entire population, then as a potential future generation, the quality of growth and development of toddlers in Indonesia needs serious attention. Health efforts undertaken since the child is still in the womb until the first five years of his life, are aimed at maintaining survival while improving the quality of life of children in order to achieve optimal physical, mental, emotional and social growth and development and have multiple intelligences according to their genetic potential (Kemenkes RI, 2015).

Having children with optimal growth and development is every parent's dream. To make it happen, of course parents must always pay attention, supervise, and care for children carefully. The process of growth and development in children or toddlers can take place naturally, but the process is also very dependent on parenting from adults or parents. The toddler period is an important period in child development. Because at that time the initial or basic growth will affect and determine the child's development in the next period. In this toddler the development of language skills, fine motor skills, gross motor skills, social, emotional, and intelligence levels run very fast and are the basis at the next stage of development. During this critical period, necessary and appropriate stimulation or stimulation is needed so that its potential develops (Nia Kania, 2016).

Speech and language stimulation is important, language and speech skills are indicators of all child development. The critical period for the development of speaking and language skills is the period between 9-24 months of life. Because the ability to speak and speak sensitive to delays or damage to other systems, because it involves cognitive abilities, sensory motor, psychological, emotional, and the environment around the child. A child will not be able to speak without the support of his environment (Soetjiningsih, 1995: 237). According to Dzulkifli, 2005 that children continue to learn to speak because they are stimulated by the urge to imitate the voices they hear spoken by others. The environment also influences language development.

Speech and language skills involve cognitive, sensorimotor, psychological, emotional and environmental development of children. Language skills in general can be distinguished by receptive ability (listening and understanding) and expressive ability (speaking). Speech ability can be judged more than other abilities so discussion about language skills is more often associated with speaking ability. Proficiency in language and speaking is 
influenced by intrinsic factors (from children) and extrinsic factors (from the environment). Intrinsic factors, which are innate conditions including the physiology of organs involved in language and speech skills. Meanwhile extrinsic factors in the form of stimulus around the child, especially words that are heard or addressed to the child.

Based on the results of a preliminary study conducted on January 19, 2019 at Posyandu Mekar Arum 18 RW 17, Bojongsoang Urban Village, using interview and observation techniques with samples taken randomly namely mothers with children under five, out of 9 mothers there were $4(44.4 \%)$ children age 2,5 - 5 years who experience language development or speech delays. The parents only found out after examining and consulting a doctor and their children were diagnosed with suspect speech delay with varied conditions.

The problem of delayed speech in children is a serious problem that must be addressed immediately because it is one of the causes of developmental disorders that are most often found in children. Delay in speech can be known from the accuracy of the use of words, which are marked by unclear pronunciation and in communication can only use sign language, so that parents and those around them are less able to understand children, even though the child can actually understand what people are talking about. Speech delays as to what is known refers to obstacles or disorders of children's development. Talking disorders in children have been previously defined as abnormal speech abilities of a child when compared to the ability of children the same age. This abnormality is known from the ability to speak a child who is under normal children at his age.

\section{METHOD}

This study uses a qualitative design that aims to dig deeper into the case of language development delays in early childhood based on the viewpoint of respondents, explore the phenomenon of factors that influence the occurrence of language delays in early childhood. The paradigm of this research is constructivism, researchers develop subjective meanings of the experiences of respondents who are directly involved in the condition of language impairment or delays in early childhood. The phenomenological approach used aims to study, develop or discover knowledge by using a scientific approach in giving meaning or interpreting a number of things that are meaningful in exploring how the process of language development delays in early childhood from several components.

The population in this study were all parents (father and mother) and early childhood (toddlers) who experienced language development delays. Respondents in this study were selected purposively with a maximum variation strategy, which is to choose research subjects who understand the problem under study from various perspectives.

A. Inclusion Criteria:

- $\quad$ Age of children 12-60 months

- Normal child/does not have a disease such as:Down syndrome, Cerebral Palsy, Autism, mute /deaf

- When testing the child in good health

- The dominant mother or father takes care of children everyday at home.

\section{B. Exclusion Criteria:}

- Children who don't live with their parents everyday.

- Children who fail / refuse the language development test (cannot be tested)

- Parents who are not able to communicate verbally well.

The data used are primary data and secondary data. Primary data collection is done by interview and direct observation of language development / ability.

\section{RESEARCH RESULTS}

This neighborhood has a Toddler Posyandu named Mekar Arum 18 which provides Posyandu services for all its citizens consisting of 143 children under five. Community characteristics in this RW dominate young families with levels of education ranging from high school to college. The characteristics of its citizens are mostly employees or employers.

In this study, early childhood children who were taken as research subjects were in the same RT environment, RT 02 where the subject obtained data and its characteristics from the data in Posyandu Mekar Arum 18 in RW 17 Rt 03. The subjects in this study had from the beginning become residents of RW 17 so that the pattern of activities and environmental conditions do not experience significant changes. From posyandu data, it is found that in RT $02 \mathrm{RW} 17$ there are about 6 children under five / early age who are detected as having language development / speech delays. This is known from the results of examinations at the Posyandu and then the parents of these toddlers are further examined at a hospital / pediatrician.

\section{A. Description of Respondent Characteristics / Identity of} Research Subjects

This study aims to explore the description / phenomenon of the development of language/speech delays in early childhood in RW 17 Bojogsoang Village, Kab. Bandung. Research / data collection with in-depth interviews / in-depth interviews have been carried out on 4 children of the subject of research as primary / primary informants (father and / or mother of children) and 2 secondary informants (kindergarten teachers from 2 research subjects).

TABLE I. DESCRIPTIONS OF RESEARCH SUBJECT CHARACTERISTICS

\begin{tabular}{|c|c|c|c|c|c|c|}
\hline No & $\begin{array}{c}\text { Subjeck } \\
\text { Code }\end{array}$ & Name & Date Of birth & $\begin{array}{c}\text { Age } \\
\text { (month) }\end{array}$ & Gender & Adress \\
\hline 1. & An.1 & M. Irvin & Bdg, 19-2-2014 & 53 & Male & $\begin{array}{c}\text { Kinagara D.5 } \\
\text { RW.17 RT02 }\end{array}$ \\
\hline
\end{tabular}




\begin{tabular}{|c|c|c|c|c|c|c|}
\hline No & $\begin{array}{c}\text { Subjeck } \\
\text { Code }\end{array}$ & Name & Date Of birth & $\begin{array}{c}\text { Age } \\
(\text { month })\end{array}$ & Gender & Adress \\
\hline 2. & An.2 & Azwan.A & Bdg, 28-8-2014 & 60 & Male & $\begin{array}{c}\text { Kinagara B1.10 } \\
\text { RW.17 RT02 }\end{array}$ \\
\hline 3. & An.3 & Ansar & Bdg, 24-4-2015 & 51 & Male & $\begin{array}{c}\text { Kinagara C.14 } \\
\text { RW.17 RT02 }\end{array}$ \\
\hline 4. & An.4 & M. Devan & Bdg, 1-7-2014 & 60 & Male & $\begin{array}{c}\text { Kinagara C1.20 } \\
\text { RW.17 RT02 }\end{array}$ \\
\hline
\end{tabular}

In this study there are several parties involved and have an important role in supporting research. Various information data obtained through primary and secondary informants in the study. The following are the identities of the primary and secondary informants / informants of the study.

TABLE II. DESCRIPTION OF MAIN INFORMANTS

\begin{tabular}{|c|c|c|c|c|c|c|c|c|}
\hline No & $\begin{array}{c}\text { Informant } \\
\text { Code }\end{array}$ & Name & $\begin{array}{c}\text { Age } \\
\text { (Year) }\end{array}$ & Education & Profession & Gender & Religion & Adress \\
\hline 1. & Ortu.1 & Bu Neli & 33 & D3 & Worker & Female & Islam & $\begin{array}{c}\text { Kinagara } \\
\text { RW.17 RT02 }\end{array}$ \\
\hline 2. & Ortu.2 & Bu Tari.R & 34 & SMA & Housewife & Female & Islam & $\begin{array}{c}\text { Kinagara B1.10 } \\
\text { RW.17 RT02 }\end{array}$ \\
\hline 3. & Ortu.3 & Bu Feni & 33 & D3 & Nurse & Female & Islam & $\begin{array}{c}\text { Kinagara C.14 } \\
\text { RW.17 RT02 }\end{array}$ \\
\hline 4. & Ortu.4 & Bu Nani & 36 & SMA & Housewife & Female & Islam & $\begin{array}{c}\text { Kinagara C1.20 } \\
\text { RW.17 RT02 }\end{array}$ \\
\hline
\end{tabular}

TABLE III. DESCRIPTION OF SECONDARY INFORMANTS (TRIANGULATION)

\begin{tabular}{|c|c|c|c|c|c|c|c|c|}
\hline No & $\begin{array}{c}\text { Informant } \\
\text { Code }\end{array}$ & Name & $\begin{array}{c}\text { Age } \\
\text { (Year) }\end{array}$ & Education & Profession & Gender & $\begin{array}{c}\text { Religi } \\
\text { on }\end{array}$ & Adress \\
\hline $\mathbf{1 .}$ & 01 & $\begin{array}{c}\text { Bu } \\
\text { Yetty }\end{array}$ & 36 & S1PAUD & $\begin{array}{c}\text { Teacher } \\
\text { TK }\end{array}$ & Female & $\begin{array}{c}\text { Islam } \\
\text { Ciganitri } \\
\text { RW.9 RT08 }\end{array}$ \\
\hline $\mathbf{2 .}$ & 02 & Bu Rini & 33 & S1PAUD & $\begin{array}{c}\text { Teacher } \\
\text { TK }\end{array}$ & Female & Islam & $\begin{array}{c}\text { Bojongsoang RW.6 } \\
\text { RT.01 }\end{array}$ \\
\hline
\end{tabular}

The results of this study are 9 factors that affect language development delays in early childhood, namely multilingualism, lack of knowledge of language development barriers, health, intelligence, physical readiness to speak, mental readiness to speak, good models to emulate, lack of motivation to speak, and guidance. In addition to these factors, there are 4 factors that are the findings in this study, namely the habits of children in watching television, the lack of knowledge about the delay in talking by people around the child, gender, relationships with peers.

The implementation of this research is to reduce the habits of early childhood to be passive subjects when watching television, especially to increase parents' knowledge about the delay in language development in early childhood, eliminate the paradigm that boys should not be fussy or talk too much like girls, and provide more opportunities for young children to interact actively with children their age.

\section{RESEARCH DISCUSSION}

\section{A. Speech Delay}

According to Hurlock (1978: 194-196), it is said to be late talking if the level of speech development is below the level of quality of development talk to children of the same age that can be seen from the accuracy of use 31 the word. If when their peers talk they use the words, while the child continues to use baby's gestures and speech styles then the child is considered someone else too young to be invited to play.
Whereas in Papalia (2004: 252-253) explains that children are late talking is a child who at the age of 2 years has a wrong tendency in saying a word, then having a bad vocabulary at the age of 3 years, or also has difficulty in naming objects at age 5 year. And children like that, will not have the tendency able to read. "Children who show an unusual tendency to mispronounce words at age 2 , who have poor vocabulary at age 3 , or who have trouble naming objects at 5 are apt to have reading disabilities later on "Based on the opinion of Hurlock (1978: 194-196) and Papalia (2004: 252- 253) which has been explained above, it can be concluded that the definition of a child is experiencing delayed speech is a child's level of developmental quality talk the same as a kid his age.

\section{B. Factors Causes Delay in Speech}

There are many causes for delay in speaking, the most common is low level of intelligence that makes children impossible to learn speak as well as their peers with normal intelligence or height; lacking motivation because children know they can communicate adequately with the parent's impulse form of speech to continue to use "baby talk" because they think so "sweet"; limited opportunities for speaking practice due to tight boundaries 32 about how much they are allowed to talk at home; continously associating with twin brothers who can understand their special sayings and the use of foreign languages at home which slows learning mother tongue. 
One cause that is undoubtedly, the most common and most serious is the inability to encourage children to talk, even when the child start chattering. If the child is not encouraged to chatter, it will inhibit the use of vocabulary and they will continue to lag behind friends of their age who get the urge to talk more. The lack of encouragement is a serious cause. Lateness talk can be seen from the fact that when parents don't just talk to their child but also uses a wide variety of words, the ability to speak children will develop quickly (Hurlock, 1978: 195-196).

\section{CONCLUSION}

The results of the study are 13 factors that influence language development delays in early childhood: multilingualism, lack of knowledge about language development barriers, health, intelligence, physical readiness to speak, mental readiness to speak, good things to imitate, lack of motivation to speak, children's habits when watching television, lack of knowledge of people around children, gender, and relationships with peers.

\section{REFERENCES}

[1] Azwar, Saifudin, (2009). Sikap Manusia dan pengukurannya. Pustaka Pelajar. Yogyakarta: hlm 4-6.

[2] BKKBN. 2011. Tumbuh Kembang Anak. Jakarta BKKBN

[3] Dinkes. (2011). Profil Kesehatan Provinsi Jawa Barat. Bandung: Jawa Barat

[4] Endang Buda Setyowati. 2010. Hubungan Antara Pengetahuan, Sikap dan Perilaku Ibu dengan Perkembangan Bahasa pada Anak Usia 24-36 Bulan di Krembangan Surabaya. Tesis tidak diterbitkan. Fakultas Kesehatan Masyarakat UNAIR.Surabaya.

[5] Hamdani, dkk. (2006). Psychosocial Stimulation Improves the Development of Undernourished Children in Rural Bangladesh.http://nutrition.highwire.org/content/136/10/2645.fu 11. (Diakses tanggal 15 Februari 2019)

[6] Hermawan, 2011. Permainan Edukatif. http//www.intramedia. net. Akses 22 Maret 2019

[7] Imelda. 2017. Pengetahuan Ibu Tentang Pemberian Stimulasi Dan Perkembangan Anak Pra Sekolah (3-5 Tahun) Di Banda Aceh. Idea Nursing Jurnal. ISSN : 2087-2879, e-ISSN : 2580 2445 Vol 3. No.3 2017.

[8] Kania, Nia. (2006). Stimulasi Tumbuh Kembang Anak untuk Mencapai Tumbuh Kembang yang Optimal. Materi Seminar "Stimulasi Tumbuh Kembang Anak". Bandung.IDAI. (diakses pada 24 Februari 2019)

[9] Kementerian Kesehatan RI. (2015). Profil Kesehatan Indonesia Tahun 2015. Jakarta. Kusuma, Hendra dkk. 2012. The Relationship of Mother's Science About Educatif Games With Of chidren 3-5 Years To The Posyandu At Village The Mojokrapak Tembelang Sub-District Of Jombang District. Nursing News:Jurnal Ilmiah

[10] Mahasiswa Keperawatan.Vol. 2 No. 2 (2017) (diakses tanggal 21 Maret 2019) Soetjiningsih. (2003). Tumbuh kembang anak. Jakarta: EGC.

[11] Sugiyono. 2014. Metode Penelitian Pendidikan Pendekatan Kuantitaif, Kualitatif dan R\&D. Bandung: Alfabeta.

[12] Syamsu. 2011. Psikologi Perkembangan. Jakarta: ISBN.

[13] Tentama, Fatwa dkk. 2015. Modul Keterampilan Stimulasi Anak.Fakultas Psikologi UAD. Yogyakarta (dikases pada 2 Maret 2019)

[14] Soetjiningsih. Buku Ajar Tumbuh Kembang Remaja dan Permasalahannya. Jakarta: Sagung Seto. 2007.

[15] Ertem, O. I. et al. Mothers' Knowledge of Young Child Development A Developing.

[16] Rita kurnia. 2009. Metodologi pengembangan bahasa anak usia dini. Cendikia insani. Pekanbaru.

[17] Martini Jamaris. 2006. Perkembangan dan pengembangan anak usia taman kanak- kanak.Grasindo. Jakarta.
[18] Creswell J.W. Research Design. Pustaka Pelajar. 2010; 3-30, 258-301.

[19] Norman K. Denzin YSL. Handbook of Qualitative Research Yogyakarta:Pustaka Pelajar;2009 